DOI: $10.22559 /$ folklor.949

Folklor/edebiyat, cilt:25, say1: 97-1, 2019/1

\title{
Dil Öğreniminde Öğrenci Bağışıklığının Dinamik Gelişimi
}

\author{
The Dynamic Development of Student Immunity in Language Learning \\ Motivation
}

\author{
Semiha Gürsoy* \\ Şehnaz Şahinkarakaş***
}

\begin{abstract}
In a study, the distinguishing professor Hiver (2015) introduced a new concept to the education field called "teacher immunity", proposing that it emerges through the broad experiences of coping with the uncertainties and potential problems of teaching occupation which functions as an indispensable armor to survive as a teacher. As a matter of fact, many foreign language (FL) learners are struggling to continue their learning journey despite the numerous damaging factors which can have an effect upon their desire to learn. Some of these students have the ability to cross over these hurdles via their own self-motivation and self-organizing strategies, while others find themselves inadequate to deal with such problems possibly because they are unaware of their sense of self and identity. The other area which is open to a question is that whether this concept can raise students' consciousness and make the necessary transformative change on their motivation so that it redevelops more productively to carry on their language learning journey despite its adversity. To do this, a data-driven case study was designed to investigate whether there is the emergence of any stages which can be termed as "student immunity" (the coping strategies students acquire in time) through the lens of CT and to reveal those factors which constitute student immunity. The qualitative interview data suggested that an emergent outcome, student immunity, was developed in return for disturbances which were confronted by the subject student in her/his school-life experience. The new emergent outcome became visible to function as a defense system to be able to sustain on an ongoing basis to deal with relatively ongoing academic difficulty.
\end{abstract}

Keywords: complexity theory, self-organization, sense of self, student identity, student immunity, motivation 
Öz

Hiver (2005) uyguladığı çalışmalardan bir tanesinde, eğitim alanına “öğretmen bağışıklığg” adında yeni bir kavram sunmuştur ve bu bağışıklığın öğretmenlik mesleğinde belirsizlikler ve potansiyel sorunlarla baş edebilme tecrübesiyle zamanla kazanıldığı ve bu mesleği devam ettirebilmek için elzem bir unsur olarak işlev gösterdiği yargısına varmıştır. Zamanla gelişip yerleşen bu bağışıklık sistemi biyolojik bağışıklık sistemi ve psikoloji alanındaki yerleşik temeller çıkış noktası olarak alınıp, Kaos Teorisinden “öz örgütleme” çerçevesine dayandırılarak açıklanmıştır. Bir çok yabancı dil öğrencisi de öğrenme motivasyon ve isteklerini etkileyebilecek sayısız negatif etkene rağmen dil öğrenmeye devam edebilmek için uğraşmaktadırlar. Bu öğrencilerin bir kısmı, bu engelleri kendi öz motivasyonları ve kendi kendini organize eden stratejiler aracılığıyla geçebilme yeteneğine sahipken, diğerleri bu tür problemlerle başa çıkma konusunda kendi öz ve kimliklerinden habersiz olduklarından kendilerini yetersiz bulmaktadırlar. Bu bağlamda, bu çalışma aynı bağışıklık sisteminin öğrenciler açısından da öğrenme sürecinde var olup olmadığı, varsa nasıl işlediği ve hangi faktörlerin öğrenme bağışıklığı oluşturma sürecinde etkili olduğu konusunu araştırmada merak uyandırmıştır. Ucu açık olan diğer bir soru da, bu kavramın öğrencilerin bilinçlerini arttırabilmelerinin ve motivasyonları üzerinde gerekli dönüştürücü değişimi yapabilmelerinin, bu yüzden de olumsuzluklara rağmen dil öğrenme yolculuğunu sürdürebilmek için daha üretken bir şekilde yeniden geliştirebilmelerinin mümkün olup olmadığıdır. Araştırma sonucunda $\ddot{o} \breve{g} r e n c i ~ b a \breve{g} l s ̧ ı k l ı \breve{g} l$ öğrencinin okul hayatında karşılaştığı sorunlar veya rahatsızlıklar karşısında bir nevi öğrenmeye devam edebilmek için yeni özellikler edinmiştir. Ortaya çıkan bu yeni durum, devam eden akademik zorluklarla başa çıkabilmek ve bu durumu devam ettirebilmek için bir savunma sistemi olarak işlev görmeye başlamıştır. Yeni ortaya çıkan sonuç, devam eden akademik zorluklarla başa çıkabilmek ve bu durumu sürekli bir şekilde sürdürebilmek için bir savunma sistemi olarak işlev görmeye başladı.

Anahtar sözcükler: karmaşıklık teorisi, öz-örgütleme, benlik algısı, öğrenci kişiliği, öğrenci bă̆lşıklı̆̆l, motivasyon

\section{Introduction}

Motivation of human beings has its roots in distinctive disciplines along with science, sociology, psychology, and education as well. In simplified terms, motivation gives behavior its energy and direction (Reeve, 2005, as cited in Gregersen \& McIntyre, 2013). Admittedly, it is the key concept in the Second Language Acquisition (SLA) which influences the desire to learn. In his distinguishing study, Hiver (2015) strived to find out the secret of surviving as a teacher despite its uncertainties, work load, emotional and physical stress and heavy pressure. In his own term, he outlined the theoretical features of "teacher immunity" with its four stages (1-triggering, 2-coupling, 3-re-alignment, and 4-stabilisation) through the lens of complexity theory (CT) and discussed its contribution to understand their sense of self and identity by means of the self-organization process which keep them away from quitting their teaching profession. 
However, apparently no published reports of subsequent research with "student immunity", in other words, the motivating factors that keep them continue their learning journey exists. If the so called "teacher immunity" can be materialized and reorganized in a productive and robust manner as shown by Hiver (2015), then it could also be possible to follow a similar procedure in terms of students' perspectives. Therefore, the intent of this research is to explore the issue of precisely what psychological qualities set apart L2 learners who are motivated, committed, productive, and emotionally well-adjusted and who struggle to keep on learning from those who are just the opposite. Instead of generalizing the results and assuming that they fit each learner any time, we utilized the information about what is going on at a particular moment in time through the Dynamic System Theory (DST) which "allows researchers in L2 motivation to simultaneously abandon the notion of single and linear causality and frees them from the implicit demand in conventional research for large subject studies" (Schumann, 2014 in Dörnyei, McIntyre \& Henry, p. 16). While investigating individuals, DST principles serve as a useful tool that "allows us to see our research enterprise in terms of complex systems, not just as the phenomenon of motivation..." Hopefully, the findings might serve as a guideline to determine how learners can achieve optimal learning effectiveness.

\section{Student Immunity}

Immunity refers to the condition of resistance against something or exemption from something (e.g., as with diplomatic immunity, or judicial immunity (Chiapelli \& Liu in Hiver, 2016). Biologically, the immunity system "is a network of cells, tissues, and organs that work together to defend the body against attacks by "foreign" invaders (National Institute of Allergy and Infectious Diseases, 2003, p.1). It is responsible for avoiding or minimizing the impact of attacks from inside and outside the human body through fighting with infections and destroying abnormal cells (Hiver, 2016). It can be defined as a defense system that protects the organism against the negative, undesirable or harmful impact of the external environment. In this regard, great numbers of valuable studies in the past 40 years have revealed the relationship between negative emotions and its effects on the immunity system as excessive psychological stress has augmenting impact on the body. As a matter of fact, it could be useful to investigate the "existence of psychological parallels to biological immunity" (Hiver, 2016, p.52).

\section{Literature review}

Research on language learning motivation was first initiated by Gardner and Lambert (1972) and the issue was extended by many other associates later on (e.g. Clement and Gardner, 
2001; Gardner and McIntyre, 1991, 1993; Tremblay and Gardner, 1995). The researchers developed a motivational theory which was adopted from a social-psychological view using standardized assessment instruments derived from empirical data through their scientific research. The key component of Gardner's (1985b) motivation theory was integrative motivation which is explained as the state that when a learner has the desire to learn a language to communicate with people who speak it. Instrumental motivation, on the other hand, refers to the situation when a learner benefits from second or foreign language. Learners have more operational aims such as getting a good job, passing an exam or visiting a foreign country. Nevertheless, this characterization of instrumental and integrative duality has later been accepted as too simplistic as the definition does not account the dynamic nature of the motivation issue. Gardner's model has been questioned as it is only limited to general motivation and criticized as being concerned with the social environment of L2 learning. Dörnyei (1994) pointed out that Gardner and his colleagues' studies were mostly conducted in the SLA context where there is a direct interaction with the target language community. However, this is not the case for Foreign Language Acquisition (FLA) contexts as the target language is taught as a school subject in a school environment. As it is pointed out by Dörnyei (1994), "the exact nature of the social and pragmatic dimensions of L2 motivation is always dependent on who learns what languages where" (p.275). Hence, by the end of 1990's, there was a shift from general motivation perspective to a more broadened, different motivational dimensions with a variety of new models and approaches which was resulted in Gardner and Tremblay's (1994) own word, "motivational renaissance” (Dörnyei, 2005). These new approaches attempted to study the motivation issue in learners' immediate learning environment which influences their overall state as well. With this new eclectic approach, motivation research has found more fertile ground for theoretical developments, which Dörnyei (2005, p. 10) considers as "three particularly forward-pointing: the process-oriented conceptualization of motivation, the reinterpretation of the integrative motive and finally the reframing of L2 motivation as part of the self system". This also supports the notion that each learning environment and context should be regarded specific and treated accordingly. Yet, Gardner's model is still a useful tool to characterize the motivational structure and also can be taken as a starting point to move on to identify further directions in the field. To achieve this aim, "complexity is a meta-theory which provides powerful conceptual tools for investigating complex outcomes and dynamic patterns of change" (Hiver, 2015, p. 116).

\section{Dynamic motivation}


The Dynamic System (DST) is a theory of development which has its roots from complex and non-linear systems in physics and mathematics. Dynamic systems try to understand the elements that cause change over time. DST gives an insight about the theoretical principles to conceptualize and regulate the complex and interrelations of time and process. When Dörnyei and Otto (1998) conceptualized their process model to define the dynamic character of motivation, they focused on the language related event before, during, and after it takes place. They identified numbers of stages in this model which gives a person his/her energy to begin the action and then other complex adjusting processes that are responsible for controlling learners' action mechanisms (Gregersen \& McIntyre, 2013).

The significance which distinguishes the process model from that of Gardner's model is that "it describes ways in which motivational adjustments are made on a continuous basis" (Gregersen \& McIntyre, 2013, p. 110) as DST tries to see the notions from a number of different causes with non-linear causality and mutable categories (Schuman, 2014). As a matter of fact, the motivation issue is no longer out of the scope of dynamic systems as it paves the way for uncovering the process that describes such system.

The terms self-organisation and emergence are the concepts which usually appear together in dynamical systems. Self-organisation is the central process of DST, and it refers to a change in the system without the help of an external agency and formation of a novel outcome (Banzhaf, 2009). Emergence, on the other hand, is an essential quality of self-organising systems. Brunner and Klauninger (2003) suggest that "the notion of emergence means that a system is more than the sum of its parts and that a developing system has new qualities that cannot be reduced to old states or prior existing systems" (p. 10). Although these two concepts show some similarities in terms of being dynamic and robustness, they do differ in the way they refer to. "Emergence is robust with respect to the flexibility in the specific parts that cause the emergent properties while self-organisation is robust with respect to the adaptability to change and its ability to maintain the increased order" (De Wolf \& Holvoet, 2005, p. 9). What we should keep in mind is that, although they occur in isolation, the combination of both is often present in complex dynamical systems, and it is an encouraging approach to regulate multiagent systems.

Even though we have gained deep and invaluable insights from experimental methods and single-causal variable investigations that extended our knowledge, studies conducted through DST framework could make it more available to see the intra-individual variation in 
L2 learning rather than focusing only on inter-individual variables between groups and can also eschew us accepting averages as the truth (Schuman, 2014).

\section{Constructs of Student Immunity}

The psychological constructs which were thought to have some parallels to student immunity were specified as "academic resilience", "academic hardiness", "academic buoyancy", and "students' coping strategies". Academic resilience is a psychological construct observed in some individuals that accounts for success despite adversity. It reflects the ability to bounce back, to beat the odds and considered an asset in human characteristic terms. Academic hardiness, on the other hand, refers to students' state of being flexible to academic failure. Those hardy students are generally eager to take part in challenging academic works, they show self-dedication to academic activities and pursuits, and they usually have control over their academic performance and outcomes (Benishek\& Lopez, 2001). The study of hardiness in academic settings is particularly relevant as the academic environment can be damaging and competitive for students (Creed, Conlon, \& Dhaliwal, 2013). Academic buoyancy is basically, dealing with everyday academic setback in the ordinary course of school life such as poor performance, competing deadlines, performance pressure, difficult task, and it has also been described as one factor that assists students to deal with academic risks which particularly occur relatively frequently and on an ongoing and everyday basis (Martin \& Marsh, 2009). The last construct, Students' coping strategies (SCOPE), refers to the styles and strategies of students that they try and use to deal with setbacks and adversities they face in their academic environment so that they can manage things better and be more successful (Struthers, Perry, \& Menec, 2000).

\section{Research design}

This study followed exploratory case study, a qualitative approach, as our purpose was to gain a deeper understanding of psychological qualities of motivated and committed students. Qualitative research methods allow researchers to have a better comprehension of any social phenomenon in the natural setting of a participant (Bryman, 2004) and they also provide detailed and elaborated information about the phenomenon under investigation (Schmidt, 1983). In the following section the participants, the techniques, and the data analysis process will be presented.

Research Question 
Although sustained motivation lies in the heart of learning a foreign language, achieving sense of stability and the underlying factors that keep that stability under control to handle the learning process has gained very little attention. Concerning this issue the research question was then formulated as follows:

What are the factors that constitute student immunity?

\section{Participants}

This study was carried out in a Private University in Turkey. The participant student for the Case Study was a 21 year-old motivated and committed university student, Rosie (the real name of the participant has been changed throughout the whole article), in a beginner level of a Preparatory School. Rosy was chosen because her resilience and success were verified by her teachers, her exam results and also by the high results from four relevant quantitative questionnaires which were thought to have effects on student immunity. She had some hard times in the past and also at the time of the case study in learning a foreign language but obviously, she has never given up studying for that. With her own strategies and endurance, she got over the hardship of language learning. As a matter of fact, she was thought to have gained some kind of language learning immunity which has kept her go on her learning journey. Rosie's participation was voluntary and she agreed to share her language learning experiences with her feelings.

In casing Rosie, four relevant questionnaires, which were thought to identify immune student, were also determined from the literature. The selected questionnaires were;

1- The Academic Buoyancy Scale (ABS; Martin \& Marsh, 2008).

2- The Academic Resilience Scale (ARS-30) (Cassidy, 2016).

3- The Academic Hardiness Scale (AHS; Benishek\& Lopez, 2001).

4- Students' Coping Strategies (SCOPE; Struthers, Perry, \&Menec, 2000).

The Academic Buoyancy Scale is comprised of five different aspects including selfefficacy, uncertain control, anxiety, academic engagement, and teacher-student relationship. The Academic Resilience Scale, on the other hand, comprises perseverance, reflecting and adaptive help-seeking and negative effect and emotional response parts. The areas covered by The Academic Hardiness scale are commitment, challenge, and control. Students' Coping 
Strategies scale included problem focused coping and emotion focused coping. All the answers to the scales ranged on a scale from 1 (Strongly Disagree) to 5 (Strongly agree). Each scale was given to three different levels (beginner, elementary, pre-intermediate) of Preparatory School of a University in Turkey (51 students). The results were calculated using PASW Statistics 20 Predictive Analysis Software - formerly SPSS. When the mean scores were taken into account (Table 1), it was found that Rosie had considerably high scores from each of the scales compared to other students' scores. Hence, Rosie, who got higher points from the scales, was also requested to participate in the Case Study part of the survey.

\section{Table 1}

Descriptive statistics of Rosie's scales

\begin{tabular}{lccc}
\hline & Range & MEAN & SD \\
\hline Buoyancy & $2.18-4.88$ & 4.36 & .475 \\
Resilience & $1.55-4.51$ & 4.41 & .612 \\
Hardiness & $2.12-4.41$ & 4.26 & .638 \\
SCOPE & $1.61-4.29$ & 4.29 & .729 \\
\hline
\end{tabular}

\section{Data Collection Methods}

As it was mentioned before, qualitative methods serve as useful tools to have a better understanding of the motivation behind human behaviors (Barbour, 2008). After Rosie was determined for the case study part, personal semi-structured interview and narrative essays were selected as instruments to identify the factors or features which constitute her immunity to language learning. Narrative essays were written after the semi-structured interview was conducted during the fall semester of 2017-2018. This narration technique usually allows language learners to express their experiences and also their feelings about those experiences more smoothly (Oxford, 1995), as well as giving researchers the opportunity to go into participants' personal and private world to gain prosperous data (Pavlenko, 2007), which is the focus of this study. As a matter of fact, it is thought that this instrument would suit the findings best through identifying the factors constituting student immunity to language learning. 
Semi-structured interview from Rosie recorded and after that, it was transcribed to be able to analyze the data. Personal narrative essays were also analyzed to explore any possible emergent issues which were not considered by the researchers but the participants.

\section{Data Analysis}

To identify and integrate the nodes around the possible emerging qualities of motivated student, semi-grounded theory approach with loose expectations and qualitative comparative analysis was followed using Atlas.ti software. Grounded Theory approach allows researchers to follow analytic procedure of analyzing data which makes it possible to render process, action or interaction theory of a phenomenon under investigation (Glaser \& Straus, 1967). The data analysis was divided into two stages. First, narrative essays were read segment by segment to identify any events or feelings which enhanced or triggered the process of gaining immunity to language learning. The data were analyzed to understand the self-motivation that led Rosie to deal with language learning problems. Then, interviews were transcribed and analyzed to verify whether some of those patterns were also present in the interviews as well. Units of texts were also grouped under categories and each of them was given a title that comprised Rosie's emergent features that could be attributed to an immune student.

\section{Findings}

Based upon the above description of data analysis, Rosie's immunity to language learning emerged in four sections with their corresponding sub-categories (see Table 2). The results indicated that Rosie is a highly academically buoyant, resilient and hardy student who has enhanced coping strategies towards academic setbacks. The emerging features of the employed strategies by the case participant were shown in Table 2.

\section{Table 2}

Features of Immune Student

\begin{tabular}{|l|l|l|l|}
\hline $\begin{array}{c}\text { Academic } \\
\text { buoyancy }\end{array}$ & $\begin{array}{l}\text { Academic } \\
\text { hardiness }\end{array}$ & $\begin{array}{c}\text { Academic } \\
\text { resilience }\end{array}$ & \multicolumn{1}{|c|}{ SCOPE } \\
\hline $\begin{array}{c}\text { - Academic } \\
\text { engagement }\end{array}$ & $\begin{array}{l}\text {-challenge } \\
\text {-commitment }\end{array}$ & -perseverance & $\begin{array}{l}\text {-problem-focused } \\
\text { coping }\end{array}$ \\
\hline
\end{tabular}




\begin{tabular}{|l|l|l|l|}
\hline $\begin{array}{l}\text {-Self-efficacy } \\
\text {-Teacher-student } \\
\text { relationship }\end{array}$ & -control & $\begin{array}{l}\text {-reflective \& adaptive } \\
\text { help-seeking }\end{array}$ & $\begin{array}{l}\text {-emotion-focused } \\
\text { coping }\end{array}$ \\
& & & \\
\hline
\end{tabular}

\section{Academic Buoyancy}

Rosie was found out to be an academically buoyant student who can easily deal with everyday academic setback in the ordinary course of school life such as poor performance, competing deadlines or difficult tasks. Academic engagement, self-efficacy, teacher-student relationship, uncertain control and anxiety were the sub-categories of the investigated features of The Academic Buoyancy Scale. As expected, Rosie revealed no signs of anxiety or uncertain control features during the interview, as these were usually considered signs of an anxious, unwilling, unimmunized kind of learner. Academic engagement and self-efficacy were revealed as strong characteristic treats of the case participant which is thought to act as the driving force to overcome the problem of continuing language learning.

Rosie's academic engagement manifested itself as an effort and investment to her own learning not to get good marks but to learn and master the skills or knowledge that the schoolwork is intended to promote:

I think studying just for the exams to get high marks is not a good thing, especially while learning English! A person must study to learn something, not to get good marks (interview).

Her engagement to learn English possibly promotes her school related performance and hence, invests on the formation of her immunity to language learning. This made her realize what really important is as a language learner and also reflect upon her primary objective.

Rosie's self-belief in her capacity and chances of accomplishing her goals successfully gave her a strong sense of self-efficacy:

The grade I needed to get from the final exam wasn't very high...I knew I was going to pass easily... I studied just in case...however, I was very confident (interview).

Passing English final exams has always been a difficult, sometimes impossible and stressful task for most of the language learners in university settings in Turkey. However, Rosie's enhanced self-efficacy feelings contributed her to reduce possible feeling of anxiety and insecurity as well as giving her kind of confidence in order to achieve her final exam. 
Teacher-student relationship manifested itself adversely. However, her disappointing relations with her teachers acted as disturbing factor which led her to ace at English:

At high school, we had an English teacher who was only interested in only those she liked in the class. Their marks were always high, and she would only help them! One day I expressed my feelings in front of the class, and then decided to improve my English, just to prove that I would learn without her anyway (narration 5).

Teacher-student relation has an important role both on academic and social environment. Usually, negative relationships bring about stressful and undesirable feelings. However, it became clear that her negative relation with her teacher obviously triggered her to do better. This also shows her buoyant reaction towards the difficulties she faces in her learning process.

To sum up, Rosie's buoyancy grew out of her engagement in her academic schoolwork and keeping up with her main purpose of language learning as well as her self-efficacy to accomplish the necessary tasks in this process. Teacher-student relationship factor also had a great effect on forming her buoyancy on the way to build her student immunity. Although it seemed to have a negative effect on Rosie, obviously, she gained a positive learning outcome.

\section{Academic Hardiness}

Academic hardiness, on the other hand, refers to students' state of being flexible to academic failure. Rosie was generally eager to take part in challenging academic works, showed self-dedication to academic activities and pursuits, and she usually perceived she had control over her academic performance and outcomes. Challenge, commitment, and control were the sub-categories of the Academic hardiness scale and all these expected features of a hardy student were also observed in Rosy through the interview.

Rosie has always been striving for the best and also enhancing active learning. Feeling insufficient or lack contradicts with her hardy character. This state manifests itself on Rosy as below:

we had a teacher who couldn't teach properly...I didn't feel like learning anything from her classes....she couldn't teach properly! You are there to learn something but you get nothing!...it was just a waste of time...So, I didn't want to attend the classes those times (interview). 
Feeling that she was not making any progress or not contributing to her language learning process depicted her challenging character in the academic setting demanding high achievement.

As for the commitment construct, Rosie can be considered as a committed student who is able to evaluate the outcomes of her actions and is usually successful at confronting the negative outcomes and finding alternative ways of attaining goals.

I would like to see myself in a good position in the future! I want to make my dreams come true. I try to get the things I want and go to all lengths for that (interview).

Rosie's will to achieve her dreams has obviously made her a committed student to her academic tasks. Obviously, she is willing to take alternative actions until she accomplishes her goals.

University education brings about some academic demands such as having autonomy, heavy pressure to excel, changing social environment as well as new roles and responsibilities. (Respondek, Seufert, Stipnusky \& Nett, 2017). Besides being challenging and committed, having control over the success or failure of achievements is another important characteristic which influences Rosie's beliefs in her capacity to be academically hardy. Rosie seemed to have gained her self- control to fulfill and to achieve all these demands whatever it takes. As she pointed out:

When I get bad marks....well, nothing is definite yet...who knows what will happen?? I will still do my best, try hard....maybe I'll take some extra help, make use of other things (interview).

Even when things go wrong, she does not feel disappointed in the first place as most of other students do. Her control over her capabilities makes her a strong character who can handle academic adversities and possibly gives her the necessary fuel to stick to her purposes.

\section{Academic Resilience}

Among the perseverance, reflective and adaptive help seeking, and negative effect and emotional response elements of academic resilience scale, the factors which have constituted Rosie's resilience manifested itself in terms of perseverance and reflective and adaptive helpseeking constructs but not negative effect and emotional response. It was not unexpected because as in the uncertain control and anxiety elements of the academic buoyancy construct, negative effect and emotional response features include, as it can also be inferred from the name, negative feelings such as anxiety, destruction, avoiding negative emotional responses 
and hopelessness (Cassidy, 2016). One of the reasons of selecting Rosie as the case participant was her strong and mostly positive characteristic. Both quantitatively and qualitatively, through interviews, her responses generally revealed positive constructs, which was expected to call her an immune student.

Cassidy (2016) identifies the features of perseverance factor as being hard working sticking to the plans that have been made and also not giving up easily. Rosie is a kind of student who can turn the crisis into opportunities. As can be viewed from her interview, risks, adversities or even failure for once do not keep her away from her goals, or cause despair:

If I failed the class...well, I would go to the summer school...or go to an English course, or take some extra courses, or get some help from a tutor...I don't know...BUT NO, I wouldn't lose my interest into the course, I wouldn't give up! (Interview).

She neither accepts failure easily nor feels anxious in the case of negative events. Rather, she can easily adjust herself in her new position and tries to manage the process as is required.

As for the reflective and adaptive help-seeking factor, Rosie is able to reflect on her strengths and weaknesses as well as looking for support and help or seeking alternative ways to study. She excels at monitoring the efforts she puts and also steering possible outcomes for her achievements:

I have been keeping a vocabulary notebook since the high school. I sometimes write their meanings and their pronunciations then, I try reading them during breaks....I think knowing more vocabularies is something advantageous. Sometimes you understand an English passage or a text from its vocabularies even if their grammatical structure is difficult to understand (narration 3).

Her reactions towards stressful events and returning back to her normal functioning with her ability to reflect on her capabilities shows her resilience feature in an academic context.

\section{Students' Coping Strategies}

The aim of the semi-structured interview was also to investigate the signs of strategies and to find out whether they really exist within the features of an immune student. The interview also revealed that an immune student has some kind of self-strategies that she enhanced to be able to function in an academic environment and manage stresses. Rosie revealed two kinds of strategies in the interview, problem-focused and emotion-focused coping strategies. 
Her problem-focused coping is the type of coping in which she tries to get over or alter negative or stressful emotions either by steering her feelings into a more positive, helpful direction or trying different strategies to neutralize the source of that problematic event. This kind of coping strategy was observed in Rosie:

My roommate was very anxious about her English class. She thought that she would be unsuccessful as her classmates knew some English and they were better than her. She was affected by the environment too much! This is not the solution! I think she should have focused on her own problems, deal with her own learning, like getting help from the teacher, or may be changing the level of her class (interview).

As it has been the case all through the interview, obviously, whenever she faces a stressful event, Rosie has enhanced some kind of coping strategies to deal with that. Unlike most of the other students would do, she does not accept failure easily, get upset or look for a support from family or friends. Instead, she thinks it should be taken an action directly towards the source of the problem to resolve any distracting feeling or event.

Emotion-focused coping was manifested on Rosie as managing her feelings, actions and strategies in a distressful mood and event. Rosie was found out to be managing such kind of events successfully and taking the necessary action wisely to control and secure her feeling not to be affected emotionally.

When things go wrong, I never study at first place until my mood changes. I try to pull myself together and try to get rid of those negative feelings first...I go out, read a book, and see my friends...when I feel better, I get back studying again (interview).

By the help of her avoidance oriented strategies, she can easily diminish the impact of an academic problem she faces and detracts herself from the source of the problem easily:

what keeps my temper...well I tend to think that everything will be OK...I mean, I always tend to think that things are going to be better, I tell to myself; it's something temporary...and try to show empathy towards my teachers when they act angrily to me...actually, it might be because s/he is angry at someone else... I never take it personally (interview).

This kind of distraction from a possible problem helps her to reduce her stress level and makes her feel emotionally better and healthy. Rosie seemed to have developed these strategies as she is aware that it is possible to encounter numerous negative events during her language learning 
process. By the help of these features, she feels ready and prepared to face those difficulties and get over them successfully. Although all these problems show up as stressors and possible damaging factors in an academic environment, Rosie has successfully changed these negative feelings into a positive outcome and experience so that she has promoted her own language learning process.

\section{Discussion}

Keeping the language learning motivation stable is different and also much more challenging than the other forms of learning motivation as it involves diverse range of skills, dispositions, goals and beliefs as well as a set of knowledge. In all of the data so far discussed, it is visible that the participant student's system is dislodged in response to disturbances and she had to overcome by the sense of despondency through developing some kind of resistance, which is called student immunity. This immunity allows the student to deal with the actual learning situations with its complex backgrounds, necessities and conflicting goals and motives. Developing such kind of attribution seems vital for the participant learner in terms of language learning context to contribute to her success and sustainability and it also has a facilitative role on making the necessary transformation on her belief system to control her own learning so that she can keep her personal equilibrium in the face of threats and adversities.

In an educational context, self-concept theory makes it possible to observe one's past, now and possible future potentials to make the necessary predictions about his/her future. The theory helps to have an idea about who "the person one was in the past, is now, and can become in the future, including social roles and group memberships" (Lee \& Oyserman, 2008; p.1). An individual's possible selves function as the indicator of the current view of the "self" and it also has a facilitative power on the formation of one's future behavior (Marcus \& Nurious, 1986). As a matter of fact, it could be concluded that L2 motivation is not a fixed attribute which can be inherited and lived by through the life (Henry, 2015).

In a study, Prasangani (2014) searched for the factors that motivate learners to learn English in Malaysia and aimed at identifying the motivational factors of these students in terms of their goals and selves while learning English. His results revealed that language learners in this context value the sense of being a member of their society and they regulate their goals accordingly so as to function successfully in it. Their motivation stemmed highly from the social norms and values of their community. 
In another study, Sternberg (2002) has found considerable relationship between motivation and language aptitude. The results showed that Belgian students were far more motivated to learn second or even a third language than French students and this is most probably not because of the language learning aptitude but because of the need for another language(s). So, Belgian students (Flemish-first language) are taught additional languages with this social demand and this reveals that although language aptitude is an effective individual variety in language learning, "motivational factors can override the aptitude effect" (Dörnyei, 2005, p.65).

In a nutshell, these studies point out that each learning environment and context is specific and should be treated accordingly. How a learner perceives and interprets the physical and emotional environment has great effect on the formation of his/her self-efficacy beliefs (Bandura, 1997). Dealing with academic adversities, the ability to lower the anxiety, having enough strength to perform highly on a task, being aware of the self and his/her own learning strategies and applying them to the learning process, and putting the necessary effort to achieve are all the features of a student who has high self efficacy belief. On the contrary, a student who has low self- efficacy will reveal the entire opposite aforementioned features and it can be predicted that this will have a negative effect on his/her capabilities, and hence on the academic success. (Mills, 2014). What is more, rather than a built-in trait, these constructs should be seen as emergent ones which are situated in the system of an immune student after dealing with certain type of conflicts in the process which are specific in educational field.

\section{Conclusion}

The argument for student immunity metaphor and the features of this immunity has evolved itself in different angles, as a part of defensive reaction to the states of adversities in an academic environment. This kind of functioning is also parallel to the development of a biological adaptive immunity. Student immunity does not come built in the system but emerges through a self-organized process as a defense system which enables an immune student to function at the peak of her effectiveness in language classrooms and do not drop out easily.

Rather than being localized, student immunity arises as kind of a situated construct which emerges and is activated in response to adversities in language learning environment. Conceptualized this way, the factors that constitute student immunity to language learning have the following features: 
Academic Buoyancy: developing academic buoyancy helps immune students to enhance the capacity to survive the hardship and challenges (e.g., poor performance, difficult tasks, exam pressure) which is an ordinary course of academic life. Academic engagement, self efficacy, and teacher-student relationship were revealed as outstanding features of academically buoyant student.

Academic Hardiness: student immunity contains a facet of hardiness which capitalizes on the commitment, challenge and control dimensions of personality characteristics. Having Academic Hardiness personality helps immune student to be involved in the event, no matter it is negative or positive (committed), gain the power to go on to influence the outcome even the situation is difficult (control), and change a crisis into an opportunity to improve the learning capacity.

Academic Resilience: having academic resilience is a distinguishing feature of an immune student as it gives him/her the capacity to strive against the major threats in an academic setting. Resilient feature of an immune student helps to turn those poor performances into successful ones and impact positively on her/his performance. Perseverance and reflective and adaptive help seeking were observed features of resilient and immune student. Although negative effects and emotional responses were possible outcome of a resilient student, these constructs appeared as having no effects upon the construction of student immunity.

Students' Coping Strategies: The coping strategies that an immune student has enhanced and used have been revealed in terms of problem-focused and emotion-focused oriented. Replanning an action plan, getting some support from tutors, sticking to objectives were viewed as problem-focused stress management while re-framing feelings into positive ones and trying to avoid negative emotions in the case of a stressful, unwanted event were observed as emotionfocused coping strategies.

As such, the constructs comprising the student immunity reflect the conceptual areas of motivation theory together with the range of traits, factors, and features commonly associated with Academic Buoyancy, Hardiness, Resilience, and Students' Coping Strategies. Findings from this study suggest that enhanced student immunity has a significant role in language learning process. L2 student immunity develops into its respective outcomes through a dynamic and emergent process. L2 student immunity may influence learners' commitment, self-efficacy, their engagement, persistence and desire to learn. This may allow them to survive and also help to raise their awareness about how to enhance self-motivation and self-organizing strategies. 
These findings also have the implication that what set apart the successful student could be that she has developed an outcome, student immunity, which other students may not have. It can be inferred that the primary function of this student immunity is to allow learners to keep up with the language learning process.

\section{References}

Bandura, A. (1977). Social learning theory. Englewood Cliffs, NJ: Prentice Hall.

Banzhaf, W. (2009). Self-organizing systems. In R. Meyers (ed.) Encyclopedia of Complexity and Systems Science (pp. 8040-8050). New York: Springer.

Barbour, R. (2008). Introducing qualitative research: A student guide to the craft of doing qualitative research. London, uk: Sage.

Benishek, L. A., \& Lopez, F. G. (2001). Development and initial validation of a measure of academic hardiness. Journal of Career Assessment, 9, 333-352. doi:10.1177/106907270100900402

Brunner, K., \& Klauninger, B. (2003). “An integrative image of causality and emergence”. In V. Arshinov \& C. Fuchs (eds.), Emergence, Causality, Self-Organization, ISBN 5956200065, pp. 23-35.

Bryman, A. (2004). Social research methods (2nd ed.). Oxford, uk: Oxford University Press. Cassidy, S. (2016). The Academic Resilience Scale (ARS-30): A New Multidimensional $\begin{array}{llllll}\text { Construct } & \text { Measure. Frontiers in Psychology, } & \text { 7, } & 1787 .\end{array}$ http://doi.org/10.3389/fpsyg.2016.01787

Chiapelli, F., \& Liu, Q. N. (2000). Immunity. In Hiver, P. (2016). Tracing the signature Dynamics of lanhuage teacher immunity. (Unpublished doctoral dissertation). University of Nottingham.

Clément, R. \& Gardner, R. (2001). Second language mastery. In H. Giles and W.P. Johnson 
(Eds.), The new handbook of language and social psychology. (pp. 489-504). New York, NY: John Wiley \& Sons.

Creed, P. A., Conlon, E. G., \& Dhaliwal, K. (2013). Revisiting the Academic Hardiness Scale: Revision and revalidation. Journal of Career Assessment, 21, $537-$ 554. doi:10.1177/1069072712475285

De Wolf, T., \& Holvoet, T. (2005). Emergence versus self-organisation: different concepts but promising when combined, Engineering Self Organising Systems. Methodologies and Applications, Lecture Notes in Computer Science, 3464, 1-15

Dörnyei, Z. (1994). Motivation and motivating in the foreign language classroom. Modern Language Journal, 78(3), 273-84.

Dörnyei, Z. and Otto, I. (1998). Motivation in action: A process model of L2 motivation. Working Papers in Applied Linguistics 4, 43-69.

Dörnyei, Z. (2005). The psychology of the language learner: Individual differences in second language acquisition. Mahwah, NJ: Erlbaum.

Gardner, R., C., \& Lambert, W.,E. (1972). Attitudes and motivation in second language learning. Rowley, MA: Newbury House.

Gardner, R. (1985b). The attitude motivation test battery: Technical report. London, Ontario, Canada: University of West Ontario, Department of Psychology.

Gardner, R. C., \& Macintyre, P. D. (1991). An instrumental motivation in language study: Who says it isn't effective? Studies in Second Language Acquisition, 13(1), 57- 72.

Gardner, R. C., \& Macintyre, P. D. (1993). On the measurement of affective variables in second language learning. Language Learning, 43(2), 157-194.

Gardner, R. \& Tremblay, P. (1994). On motivation, research agendas, and theoretical frameworks. The Modern Language Journal, 78(3), 359-368. 
Glaser, B. G., \& Strauss, A. L. (1967). The discovery of grounded theory: Strategies for qualitative research. Chicago,il: Aldine.

Gregersen, T. \& MacIntyre, P. (2013). Capitalizing on Language Learners' Individuality.

From Premise to Practice. Bristol: Multilingual Matters.

Henry, A. (2015). The dynamics of possible selves. InZ.Dörnyei, P.MacIntyre \& A. Henry (eds.), Motivational Dynamics in Language Learning, 83-94. Bristol: Multilingual Matters.

Hiver, P. (2015). Once Burned, Twice Shy: The Dynamic Development of System Immunity in Teachers. In Z. Dörnyei, P. McIntyre, \& A. Henry (eds.) Motivational Dynamics in Language learning. (pp. 214-237) Multilingual Matters.

Hiver, P. (2016). Tracing the signature Dynamics of lanhuage teacher immunity. (Unpublished doctoral dissertation). University of Nottingham.

Lee, S. \& Oyserman, D. (2008). Possible selves theory: Key terms and Processes.695-698.

Markus, H., \&Nurius, P. (1986).Possible selves. American Psychologist, 41(9), 954-969.

Martin, A. J., \& Marsh, H. W. (2009). Academic resilience and academic buoyancy:

Multidimensional and hierarchical conceptual framing of causes, correlates, and cognate constructs. Oxford Review of Education, 35, 353-370. http://dx.doi.org/ 10.1080/03054980902934639.

Mills, N. A. (2014). "Self-efficacy in Second Language Acquisition. In M. Williams and S. Mercer (ed.). Multiple Perspectives on the Self. (pp. 6-22).Multilingual Matters.

National Institute of Allergy and Infectious Diseases (2003). Retrived from:

https://www.niaid.nih.gov

Oxford, R. L. (1995). When emotion meets (meta) cognition in language learning histories.

International Journal of Educational Research, 23(7), 581-594.

Pavlenko, A. (2007). Autobiographic narratives as data in applied linguistics. Applied Linguistics, 28(2), 163-188.

Prasangani, K. S. N. (2014). Malaysian L2 learners' English learning motivation: a study of goals, attitudes, and self. Issues in Language Studies 3(1), 24-35. 
Schmidt, R. W. (1983). Interaction, acculturation, and the acquisition of communicative competence: A case study of an adult. In N. Wolfson \& E. Judd (Eds.), Sociolinguistics and language acquisition (pp. 137-174). Rowley, MA: Newbury House

Schumann, J. H. (2014). Foreword. In Z. Dörnyei, P. McIntyre, \& A. Henry (eds.) Motivational Dynamics in Language learning. (pp. XV-XIX) Multilingual Matters.

Sternberg, R. J. (2002). The theory of successful intelligence and its implications for language aptitude testing. In P. Robinson (Eds) Individual differences and instructed language learning. Amsterdam: John Benjamins.

Struthers, C.W., Perry, R.P. \& Menec, V.H. (2000), “An Examination of the Relationship among Academic Stress, Coping, Motivation, and Performance in College", Research in Higher Education, Vol. 41, No. 5, pp. 581-592.

Tremblay, P. F., \& Gardner, R. C. (1995). Expanding the motivation construct in language learning. The Modern Language Journal, 79, 505-518. 